\title{
Phytoplankton size changes and diversity loss in the southwestern Mediterranean Sea in relation to long-term hydrographic variability
}

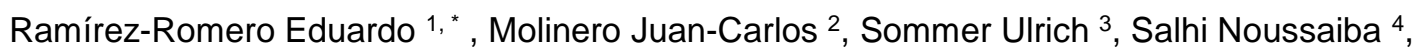 \\ Kéfi - Daly Yahia Ons ${ }^{4,5}$, Daly Yahia Mohamed Néjib ${ }^{6}$
}

\author{
${ }^{1}$ Instituto Mediterráneo de Estudios Avanzados, IMEDEA (CSIC-UIB), C/Miquel Marqués 21, 07190, \\ Esporles, Illes Balears, Spain \\ 2 Institut de Recherche pour le Développement, MARBEC, IRD/CNRS/IFREMER/UM, Sète Cedex, \\ France \\ ${ }^{3}$ GEOMAR Helmholtz Center for Ocean Research, Kiel, Germany, Marine Ecology/Food Webs, \\ Duesternbrooker Weg 20, D-24105, Kiel, Germany \\ ${ }^{4}$ Research Group on Oceanography and Plankton Ecology, Tunisian National Institute of Agronomy \\ (INAT), 43 Avenue Charles Nicolle, 1082, Tunis, Tunisia \\ 5 IRESA- Carthage University, Tunis El Manar University, LR18ES41, Tunisia \\ ${ }^{6}$ Department of Biological and Environmental Sciences, College of Arts and Sciences, Qatar University, \\ PO Box 2713, Doha, Qatar
}

* Corresponding author email address : eramirez@imedea.uib-csic.es

\begin{abstract}
:
Structural changes in plankton primary producers have large implications for food web dynamics, energy fluxes and the vertical export of biogenic particulate carbon. Here we examine phytoplankton data spanning the period 1993-2008 from the Bay of Tunis, southwestern Mediterranean Sea, in relation to long term hydroclimate variability. We show a conspicuous shift in the structure of the phytoplankton community characterized by an increase of small-sized species and diversity loss, revealing a dominance of smaller blooming diatoms and cyanobacteria. Such changes were concurrent with marked modifications in hydroclimatic patterns experienced in the Bay of Tunis consisting of a shift towards enhanced winter precipitation together with rising temperatures. This novel study shows an overall rise in the proportion of small phytoplankton cells and a decreasing trend in phytoplankton diversity in the southern Mediterranean area. These findings warn of a potential decline of trophic efficiency and lesser food web stability resulting from mean size reduction and the diversity loss.
\end{abstract}




\section{Highlights}

- Marked changes were found within phytoplankton in the SW Mediterranean from 1993 to 2008. Shifts were concurrent with rising winter precipitations and SST. An increase was found in the relevance of small-sized phytoplankton species. A diversity loss was captured in the total phytoplankton community and diatoms. Results warn on potential lesser predictable and stability ecosystem functioning.

Keywords : Size structural changes, Diversity loss, Ocean warming, Nanophytoplankton, Phytoplankton diversity, Southwestern mediterranean 


\section{1. Introduction}

2 Understanding how climate variability influence the dynamics of marine communities is

3 essential to cope with climate impacts into resources management risks under scenarios

4 of global change. Marked ecological modifications fostered by climate warming, so far

5 documented, include (i) changes in latitude/altitude species' ranges (Root et al., 2003),(ii)

6 in the timing of seasonal ecological events in organisms' life-cycle, i.e. phenology

7 (Edwards and Richardson, 2004), and (iii) a decrease in the mean body size of

8 communities (Daufresne et al., 2009); the latter being considered the third universal

9 response to warming (Peter and Sommer, 2013). Body size is a key ecological trait

10 driving physiological processes, the dynamics of trophic interactions and energy fluxes

11 in marine food webs. At the bottom of pelagic food webs, changes in dominant cells size

12 further impact biogenic particulate carbon export towards the seabed, as larger

13 phytoplankton cells sink faster than smaller ones. Hence, deciphering underlying

14 causalities of size reduction in marine ecosystems is a current ecological challenge and

15 a pressing endeavor in a changing world ocean.

17 Temperature influences phytoplankton both directly, via physiology, and indirectly,

18 through factors controlling nutrient availability. For instance, in temperate marine

19 ecosystems, high temperature foster stratification, thereby shaping light and nutrients

20 availability. Indeed, recent investigations based on meta-analysis of large data sets have

21 pointed out a leading role of resource availability in the phytoplankton size structure

22 (Marañón et al., 2015, 2012). Likewise, mesocosms experiments have shown that

23 temperature effects on cell size are mainly mediated by nutrient limitation (Peter and

24 Sommer, 2013). That is, by promoting a higher stratification, warming indirectly reduce

25 nutrients supply and primary production in surface layers, which foster a decrease of

26 large cells along with a decline in biogenic carbon export (Chust et al., 2012; Falkowski

27 and Oliver, 2007). The relationship between temperature and resource supply is however 
1 not trivial. It varies among ecosystems as nutrient inputs are also affected by upwelling

2 processes, riverine discharges or even human impact. Hence, underlying factors linking

3 warming and phytoplankton size structure are case-specific, and therefore difficult to

4 model (Marañón et al., 2015).

6 To date, a number of studies have documented a significant increase in the proportion

7 of small-sized species concurrently with warmer conditions in a variety of systems,

8 including freshwater (Strecker et al., 2004; Daufresne et al., 2009), estuaries (Guinder

9 et al., 2012) and marine ecosystems (O'Connor et al., 2009; Suikkanen et al., 2013). In

10 the Mediterranean basin, research efforts have mainly focused on northern coasts, i.e.

11 the Gulf of Naples (Ribera d'Alcalà et al., 2004), the central Adriatic (Mozetič et al., 2012)

12 and the Ligurian Sea (Goffart et al., 2002; Marty et al., 2002), where phytoplankton

13 responses to warming have shown structural changes unveiling a decline of larger cells

14 in the community. In contrast, little is known on phytoplankton dynamics in southern

15 coasts, although such areas may be more vulnerable to global anthropogenic changes

16 due to the coastal concentration of anthropogenic activities due to the increasing of

17 population density (IPCC, 2014). Furthermore, there is a lack of reports on phytoplankton

18 variability covering recent years when Mediterranean surface waters have shown

19 pronounced rising temperatures (Macias et al., 2013). Here, we compiled field data over

20 the period 1993 to 2008 from a shallow ecosystem in the northern Tunisian coast,

21 southwestern Mediterranean. We assessed hydroclimate trends, as shown by SST and

22 precipitation, and their influence on the phytoplankton community structure, e.g. size,

23 biomass, abundance and species shifts. We discussed on the impending consequences

24 on phytoplankton size structure and diversity in highly productive neritic areas under

25 projected warming scenarios in the Mediterranean Sea.

27 2. Methods 
1 Hydrological features of the Bay of Tunis are influenced by the inflowing Atlantic waters

2 in the northernmost part (Millot, 1999), whereas the southern area is characterized by

3 shallow, eutrophic coastal lagoons (Supplementary Information SI Fig. 1) (Daly Yahia-

4 Kéfi et al., 2005). The nutrient dynamics shows a zonal trophic gradient from the

5 eutrophic southwestern region to the mesotrophic northeastern area (Souissi et al., $62000)$.

\section{$8 \quad$ 2.1. Biological data}

9 Plankton samples were collected from the $5 \mathrm{~m}$ depth surface layer in two shallow stations

10 at the most inner bay $(36.76 \mathrm{~N}, 10.50 \mathrm{E} ; 36.80 \mathrm{~N}, 10.32 \mathrm{E})$, mainly with a monthly

11 frequency over the period 1993 to 2008 . The sampling was interrupted during the years

12 1996-1999, and there are as well some gaps during 2005-2006 (SI Table I). At each

13 sampling site, $1 \mathrm{~L}$ of seawater was collected using $2 \mathrm{~L}$ Ruttner bottle from the surface

14 water $(-0.5 \mathrm{~m})$ for chemical analyses and for phytoplankton counting. Samples treatment

15 over the whole period was done consistently by the same senior expert taxonomist (O.

16 Kéfi - Daly Yahia). Samples were fixed by addition of formaldehyde and acid Lugol's

17 solutions, considered at $0.4 \%$ and $3 \%$ final concentration, respectively. Subsequently,

18 samples were stored in the dark at room temperature until analysis and for long term

19 storage, samples were kept in cold place.

20 Phytoplankton cells from 25-ml subsamples were counted under an inverted microscope

21 (Hund) using 200 and 400 magnifications (Edler and Elbrächter, 2010; Utermöhl, 1958).

22 Different counting methods were used to account for the diversity of the sample

23 (Andersen and Throndsen, 2004): (i) when species are characterized by low

24 abundances, all species were counted by sweeping the entire sedimentation $25 \mathrm{~mL}$

25 chamber up and down and vice versa; (ii) one or more dominant species; cells were

26 counted along two or more transverse lines using a counting grid placed in the eyepiece.

27 Phytoplankton size fractionation for was done based on the longest axis of the cells 
1 following techniques, as described by Munawar and Munawar (1986). Phytoplankton

2 size was examined on 30 to 50 individuals of each dominant species in the sample in

3 order to ensure representativeness.

4 2.2. Physical data

5 We used regional climate data covering the period 1993-2009. Sea surface

6 temperature (SST) relative to the Bay of Tunis was obtained from Copernicus Marine

7 Environmental Monitoring Services (http://marine.copernicus.eu/). This Level-4 product

8 is specific for the Mediterranean Sea and has a $0.04 \times 0.04^{\circ}$ resolution

9 (SST_MED_SST_L4_REP_OBSERVATIONS_010_021) (Buongiorno Nardelli et al.,

10 2013; Pisano et al., 2016). Precipitation rates relative to the Bay of Tunis were obtained

11 from ERA5 climate reanalysis dataset, with $0.25^{\circ}$ of horizontal resolution (Copernicus

12 Climate Change Service, C3S, DOI: 10.24381/cds.f17050d7). We extracted monthly

13 means of daily precipitations for the entire time series.

14 In addition, we used Chlorophyll a estimates from the inner Bay of Tunis derived from

15 satellite, available from Copernicus Marine Environmental Monitoring Services

16 (http://marine.copernicus.eu/). This Level-4 product is specific for the Mediterranean

17 Sea and has a $1 \mathrm{Km}$ resolution

18 (OCEANCOLOUR_MED_CHL_L4_NRT_OBSERVATIONS_009_041; Volpe et al.,

19 2012); chlorophyll monthly means were extracted for the available period, 1998 to

202009.

\section{2.3. Statistical analysis}

22 Due to some gaps in the data series, and in order to use the longest and most coherent

23 temporal data, we pooled together phytoplankton data from the two sampled stations to

24 show the interannual variations during winter (DJFM) and summer (JJA) (SI Table I). The

25 two stations are located in shallow areas (5m, Fig. SI 1) and present a similar nutrient

26 dynamics (Souissi et al., 2000). 
1 SST series were seasonal detrended prior computing monthly anomalies and annual

2 average means. Precipitations, which occurs mainly during winter season, was averaged

3 using the same months as for phytoplankton winter variability (DJFM).

4 Periods with predominantly positive or negative anomalies were assessed by means of

5 the cumulative sum method (cusum or cusum transformed). To do this, we

6 standardized the time series to zero mean and unit variance, and then cumulate the

7 standardized values over time. Each data point, $y_{t}$, corresponding to time $t$ ( $t$ from 1 to

8 n) was added to the preceding data point according to the equation:

$9 \quad \mathrm{~S}_{t}=\sum_{t=1}^{n} y_{t}$ (equation 1).

10 The interpretation is based on the slope of the line on the chart. A constant deviation

11 from the mean of the time series shows a constant slope. Persistent changes from the

12 mean of the time series cause a persistent change of the slope. The cumulative sum

13 enables us to detect in a simple way local changes and homogeneous periods in a time

14 series (Ibanez et al., 1993).

15 In addition, we computed a driver-response plot using paired observations, on a monthly

16 basis, with a potential driver (SST and precipitations) and the chlorophyll monthly

17 anomalies as potential response. The observations were ordered following an ascending

18 order of each of the driver variable and then the chlorophyll data was transformed in a

19 cusum following equation 2. This method has been previously used to assess thresholds

20 and underlying driver-response in complex environmental time series (Regier et al., $212019)$

22 Diversity changes in the phytoplankton community were assessed by means of the

23 Shannon Index ( $\left.H^{\prime}\right)$ of phytoplankton community, following:

$24 \quad H^{\prime}=\sum_{i=1}^{R}\left(p_{i} * \ln p_{i}\right)$ (equation 2$)$, 
1 where $p_{\mathrm{i}}$ is the proportion of individuals belonging to a species $i$ per sample and $R$ the

2 total number of species per sample. A heat map was used to display interannual

3 variations of the ten most abundant species of phytoplankton, diatoms and

4 cyanobacteria. To do so, data (cells $\mathrm{L}^{-1}$ ) were ranged and a specific color was assigned

5 denoting low (blue) to high abundance values (yellow), respectively.

6

\section{3. Results}

8 The annual pattern of salinity displayed average values of $36.34 \pm 2.61$, with maximum

9 reached $38-38.8$ in August, while minimum values, ca. 26.6 -27, were registered during

10 rainy periods (from September to June). In turn, the annual pattern of SST showed an

11 average of $19.6^{\circ} \mathrm{C} \pm 4.2$, although during the last years of the series (2005-2009) an

12 upward trend was observed (Fig. 1 a, Table I). Regional climate drivers in this shallow

13 ecosystem, SST and winter precipitations (DJFM) showed statistical significant changes,

14 as described by the cusum-transformed time series (Fig. 1 a,c) (Table I). The cusum

15 results displayed two main periods, statistically significant (t test, $p<0.05)$ characterized

16 by low values during (1993-2002), followed by a shift towards higher values during the

17 years 2003-2009.

18 Chlorophyll a, as a proxy of phytoplankton biomass, followed a seasonal cycle denoted

19 by maxima during summer months in both aforementioned periods, before and after

20 2002. Minima were found during November-December ca. $0.5 \mathrm{mg} \mathrm{m}^{-3}$ and maxima during

21 June-July ca. $1.3 \mathrm{mg} \mathrm{m}^{-3}$ (Fig. SI 2). This pattern following the seasonal sunlight cycle

22 suggests there is no nutrient limitations via stratification in this shallow ecosystem

23 affected by anthropic nutrients loads from small rivers and coastal lagoons (Sommer et

24 al., 2012). Regarding the interannual variability, both summer and winter chlorophyll data

25 showed an upward shift since 2002 (Fig. 1 b,c; Table I). Both trends are tightly correlated

26 with winter precipitations, particularly summer chlorophyll values when maximum levels

27 were registered (Fig 1,c and Fig. SI 2 b). In addition, chlorophyll concentrations shifted 
1 from negative monthly anomalies to positive overcoming a precipitation threshold around

$2 \quad 2 \mathrm{Kg} \mathrm{m}^{2} \mathrm{~d}^{-1}$ (Fig. SI 4).

3

4 Phytoplankton abundance showed a marked intra-seasonal variability along with an

5 overall upward shift since 2002, reaching ca. a higher order of magnitude at the end of

6 the series, from $10^{4}$ to $10^{5}$ cells $\mathrm{L}^{-1}$ for winter values and finally reaching $10^{6}$ cells $\mathrm{L}^{-1}$

7 during summers (Fig. 2 a,b). The abundance change was mainly driven by small cells

8 (Fig. 2 b), as showed by the interannual variability of small phytoplankton $(2-20 \mu \mathrm{m}$,

9 nanophytoplankton), which displayed a significant abundance increase from $10^{2}$ to $10^{5}$

10 cells $\mathrm{L}^{-1}$ during both seasons since 2002 (Fig 2 c,d). Structural changes in the

11 phytoplankton community were further evidenced in diversity, indexed by the Shannon

12 Index $\left(\mathrm{H}^{\prime}\right)$. Phytoplankton and diatoms, the most dominant group presenting blooms

13 here, showed both a pronounced loss of diversity in winters and summers (Fig. 2 e,f; Fig.

14 SI 3).

16 The ten most abundant species recorded throughout the investigated period are shown

17 in Figure 3. Coastal areas were mainly dominated by diatoms and showed the highest

18 diversity over the years 1994-2002 (Fig.2 b,d and 3). Bellerochea horologicalis and

19 Bellerochea malleus were initially the most representative diatom species, reaching

20 typical bloom abundances in 2001-2003 (106 cells L ${ }^{-1}$, Fig. 3 and Fig. SI 5)(Hallegraeff,

21 1993). Other species, such as Thalassionema nitzschioides showed a scattered pattern

22 through the whole time series. We noticed, however, an increase of small diatoms, falling

23 within nanoplankton sizes, since 2002 with blooms of Nitzschia closterium and

24 Phaeodactylum triconutum. Particularly, P. tricornutum presented high abundances

25 reaching up to $10^{6}$ cells $\mathrm{L}^{-1}$ (Fig. 3 and Fig. SI 5). To the best of our knowledge, this is

26 the first time that such high field abundances have been reported for this diatom widely

27 used in laboratory conditions. Furthermore in the last years, cyanobacteria reached 
1 marked peaks with Merismopedia elegans as the dominant species within this group

2 (Fig. 3 and Fig. SI 5).

\section{4. Discussion}

5 We have investigated temporal changes in phytoplankton in the northern Tunisian coast.

6 The analysis revealed structural changes in the phytoplankton community, which shifted

7 towards a dominance of smaller cells along with a loss of diversity.

\section{$8 \quad$ 4.1. Hydroclimate variability and phytoplankton responses}

9 The observed phytoplankton changes closely covaried with the long-term weather

10 conditions in the southwestern Mediterranean Sea that have displayed a conspicuous

11 SST increase (Giorgi, 2006; Macias et al., 2013). Moreover, rising chlorophyll

12 concentrations in summer suggest: (i) that nutrient limitation via stratification unlikely

13 drive the phytoplankton seasonal cycle in this shallow and eutrophic area (Sommer et

14 al., 2012) and (ii) an increasing resource availability or nutrient supply (sensu Marañon

15 et al.,2015). This shallow area is affected, via precipitations, by highly eutrophic systems

16 such as coastal lagoons, small rivers and harbors receiving anthropic nutrient loads from

17 sewage and fertilizers used in agriculture (Souissi et al., 2000). Our analysis brings

18 quantitative analysis of these processes, describing a threshold of precipitations that lead

19 on high chlorophyll levels as a proxy of eutrophic conditions here (ca. $2 \mathrm{Kg} \mathrm{m}^{-2} \mathrm{~d}^{-1}$, Fig.

20 SI 4).

22 The changing environmental conditions yielded a shift from an initial dominance of

23 microphytoplankton or large cells $(>20 \mu \mathrm{m})$ before the early 2000 s to a final dominance

24 of nanophytoplankton $(2-20 \mu \mathrm{m})$ after 2003. Nanophytoplankton fall within the medium

25 size range that dominates the unimodal size-growth curve for phytoplankton, where

26 several bloom-forming species are represented (Marañón et al., 2013). Small cells may

27 outcompete large cells under increasing and less intermittent nutrient inputs, mainly due 
1 to the higher growth rates, although their storage capacity is lower. For instance, we

2 noticed a succession towards smaller diatoms, such as Phaeodactylum tricornutum,

3 which falls in the intermediate sizes presenting high growth rates (Marañón et al., 2013)

4 (see Fig. 3). Theoretical work has shown that higher and constant nutrient alters the

5 dynamics of diatoms size structure promoting a shift towards a dominance of smaller

6 diatoms (Litchman et al. 2009). In line with this, recent works stress the overlooked role

7 of small diatoms, being occasionally major contributors within phytoplankton blooms and

8 carbon export in nutrient-rich and turbulent marine ecosystems (Leblanc et al., 2018)

10 Regarding the rising abundance of cyanobacteria, an increasing presence of this group

11 has been related to warmer and eutrophic conditions (Paerl and Paul, 2012).

12 Cyanobacteria proliferations have been shown favored by higher temperatures (often

13 above $25^{\circ} \mathrm{C}$ ) and nutrient loads, where they grow better than do other phytoplankton

14 species, such as diatoms and green algae (Paerl and Huisman, 2008). We refer here the

15 cyanobacteria that fall within nano- size range, but no other smaller within

16 picophytoplankton, as Synechococcus and Prochlorococcus sp., which play a key role

17 in oligotrophic open sea ecosystems (Platt et al., 1986).

19 4.2. Biodiversity, ecosystem functioning and food web response

20 The conspicuous loss of diversity shown in the phytoplankton community is in agreement

21 with the reported global trend of marine biodiversity losses (Sala and Knowlton, 2006)

22 (Fig. $2 \mathrm{c}$ and 3). Such diversity decline warns on wide consequences at several scales,

23 as diversity stabilize resource use efficiency and overall the aquatic ecosystem

24 functioning (Ptacnik et al., 2008). In species-poor communities, resources use is less

25 efficient, which promotes available niche-space situations that may favor species

26 invasion or resource monopolization, such as the $P$. tricornutum blooms we observed 
1 during the last years of the period investigated (Fig. 2, 3). Overall, these processes within

2 less diverse communities, point to a reduced stability and predictability of the ecosystem.

4 Regarding the potential contribution of top down control, with the caveat that no

5 quantitative zooplankton data was available, it is worth noticing that gelatinous

6 zooplankton have significantly increased in the Western Mediterranean over the last

7 decades (Licandro et al., 2010; Molinero et al., 2008). Particularly in the Gulf of Tunis,

8 mild winters has been related with optimal conditions favoring Pelagia noctiluca

9 reproduction and outbreaks (Daly Yahia et al., 2010). This scyphozoan jellyfish could

10 promote trophic cascades derived from their high predation capacity (Acuña et al., 2011;

11 Brotz et al., 2012; Tiselius and Møller, 2017). Jellyfish diet consists mainly of copepods,

12 but also meroplankton, ichthyoplankton and other gelatinous zooplankton (Purcell et al.,

13 2014). However contrarily to the observed pattern, larger abundances of these voracious

14 predators may foster microphytoplankton growth by reducing copepods biomass (Stibor

15 et al., 2004; Tiselius and Møller, 2017). Hence, we suggest that the top down control by

16 copepods did not play a leading role in the observed phytoplankton changes, instead we

17 hypothesize a bottom up control driving the observed response of the phytoplankton

18 community, e.g. such as resources supply increase in this period. Moreover, these

19 structural changes in the phytoplankton community, e.g. shift in the mean community

20 size, along with larger abundances of jellyfish might further affect food web carbon

21 pathways and permeate the entire food web.

\section{4.3. Insights for Mediterranean ecosystems in the next future}

24 A concomitant warming with shrinking phytoplankton sizes has been reported in northern

25 Mediterranean regions (Marty et al., 2002; Mozetič et al., 2012, 2010; Zingone et al.,

26 2019). Nevertheless, the suggested driving mechanisms of such patterns point out a

27 leading role of an increasing stratification, as the main driver of the mixed layer dynamics 
1 and resources availability for phytoplankton. We stress that in neritic ecosystems, such

2 as the coastal sites we investigated, local or regional factors could drive the

3 environmental conditions or resource availability, leading on different responses of the

4 phytoplankton communities. For instance, a positive trend was recently registered in

5 chlorophyll from satellite data around the Nile Delta, also in the southern Mediterranean

6 coast (Lazzari et al., 2012), whereas a decrease in nutrient inputs and eutrophic

7 conditions in the Po delta (North Adriatic Sea) did not show a significant link with the

8 trend in phytoplankton size changes (Aubry et al., 2012).

10 Climate projections for the Mediterranean Sea warns on a warming trend along with a 11 decline in precipitations and more frequent extreme events (see Fig. 1 b,d) (Alpert et al., 12 2002; Hertig and Jacobeit, 2008). This scenario suggests modifications in the amount 13 and frequency of the natural nutrient supply that might foster changes in the 14 phytoplankton community (Litchman et al., 2009; Macias et al., 2010). It is worth noticing 15 however that anthropogenic nutrient loads could mask all these processes. As described 16 in previous works, the Mediterranean "tropicalization" threaten this diversity hotspot 17 (Bianchi, 2007; Vergés et al., 2014). This phenomenon is not only supported by warmer 18 and/or more oligotrophic conditions as formerly described, it also depend on local factors,

19 i.e. riverine and/or anthropogenic inputs, that may open ecological niches for tropical 20 invasive species from eutrophic systems, which may be introduced in the Mediterranean

21 Sea via ballast waters (Coll et al., 2010).

23 The analysis of long-term field data sheds light on pelagic ecosystem responses to 24 warming conditions. Phytoplankton communities are adapted to local temperatures 25 (Thomas et al., 2012), while optimum temperatures of locally adapted phytoplankton are 26 higher than the annual mean temperature they experience, and therefore the warmer the 27 local mean temperature the closer is to species optimum. This is not trivial if we consider 
1 the negative skewness of the thermal tolerance curve, which suggests that the

2 phytoplankton growth response to variations in temperature may be more sensitive to

3 warming than cooling conditions. Therefore, subtropical communities are more

4 vulnerable to warming, which may foster losses in diversity, as recently predicted by

5 global synthesis on the phytoplankton-temperature interactions (Thomas et al., 2012).

6 During the sampled period the annual mean temperature raised ca. $1^{\circ} \mathrm{C}$, while a

7 sustained increase is expected in the next century, particularly during summer months

8 (ca. 1.5-2ํ C)(Gualdi et al., 2013; Shaltout and Omstedt, 2014). This warns on drastic

9 changes phytoplankton diversity, likely shifting towards a more tropical community

10 (Thomas et al., 2012).

\section{5. Conclusions}

13 Our results pointed out conspicuous shifts in the structure of phytoplankton communities

14 likely fostered by the compound effects of rising precipitations and temperatures

15 experienced in the Bay of Tunis during the last decades. The observed changes in the

16 structure of phytoplankton community suggest a reorganization in the plankton food web.

17 Hence, southern Mediterranean warming projections, together with anthropogenic

18 nutrient inputs warn on the high vulnerability these ecosystems experience to invasions,

19 but also substantial changes in the phytoplankton diversity and size structure, which

20 ultimately will yield to a less predictable and stable system. 


\section{Aknowledgements}

2 We gratefully acknowledge the support of the European Commission: OCEAN-CERTAIN

3 (FP7-ENV-2013-6.1-1; no: 603773). Eduardo Ramirez Romero thanks the funding from

4 "Govern de les Illes Balears-Conselleria d'Innovació, Recerca i Turisme, Programa

5 Vicenç Mut."

6 


\section{$\underline{\text { References }}$}

2 Acuña, J.L., López-Urrutia, Á., Colin, S., 2011. Faking giants: the evolution of high prey clearance rates in jellyfishes. Science 333, 1627-9. https://doi.org/10.1126/science.1205134

Alpert, P., Ben-Gai, T., Baharad, A., Benjamini, Y., Yekutieli, D., Colacino, M., Diodato, L., Ramis, C., Homar, V., Romero, R., Michaelides, S., Manes, A., 2002. The paradoxical increase of Mediterranean extreme daily rainfall in spite of decrease in total values. Geophys. Res. Lett. 29, 31. https://doi.org/10.1029/2001GL013554

Andersen, P., Throndsen, J., 2004. Estimating cell numbers, in: Manual on Harmful Marine Microalgae. Monographs on Oceanographic Methodology No. 11. pp. 99130.

Aubry, F.B., Cossarini, G., Acri, F., Bastianini, M., Bianchi, F., Camatti, E., De Lazzari, A., Pugnetti, A., Solidoro, C., Socal, G., 2012. Plankton communities in the northern Adriatic Sea: Patterns and changes over the last 30 years. Estuar. Coast. Shelf Sci. 115, 125-137. https://doi.org/10.1016/j.ecss.2012.03.011

Bianchi, C.N., 2007. Biodiversity issues for the forthcoming tropical Mediterranean Sea. Hydrobiologia 580, 7-21. https://doi.org/10.1007/s10750-006-0469-5

Brotz, L., Cheung, W.W.L., Kleisner, K., Pakhomov, E., Pauly, D., 2012. Increasing jellyfish populations: Trends in Large Marine Ecosystems. Hydrobiologia 690, 320. https://doi.org/10.1007/s10750-012-1039-7

Buongiorno Nardelli, B., Tronconi, C., Pisano, A., Santoleri, R., 2013. High and UltraHigh resolution processing of satellite Sea Surface Temperature data over Southern European Seas in the framework of MyOcean project. Remote Sens. Environ. 129, 1-16. https://doi.org/10.1016/j.rse.2012.10.012

Chust, G., Irigoien, X., Chave, J., Harris, R.P., 2012. Global Ecology and Biogeography Article in Press Latitudinal phytoplankton distribution and the neutral theory of biodiversity Unlike sessile species or those dwelling on islands, oceanic planktonic species have no apparent barriers to dispersal ( Cermeñ.

Coll, M., Piroddi, C., Steenbeek, J., Kaschner, K., Lasram, F.B.R., Aguzzi, J., Ballesteros, E., Bianchi, C.N., Corbera, J., Dailianis, T., Danovaro, R., Estrada, M., Froglia, C., Galil, B.S., Gasol, J.M., Gertwage, R., Gil, J., Guilhaumon, F., Kesner-Reyes, K., Kitsos, M.S., Koukouras, A., Lampadariou, N., Laxamana, E., de la Cuadra, C.M.L.F., Lotze, H.K., Martin, D., Mouillot, D., Oro, D., Raicevich, S., Rius-Barile, J., Saiz-Salinas, J.I., Vicente, C.S., Somot, S., Templado, J., Turon, X., Vafidis, D., Villanueva, R., Voultsiadou, E., 2010. The biodiversity of the 
Mediterranean Sea: Estimates, patterns, and threats. PLoS One 5. https://doi.org/10.1371/journal.pone.0011842

Daly Yahia-Kéfi, O., Souissi, S., De Stefano, M., Yahia, M.N.D., 2005. Bellerochea horologicalis and Lithodesmioides polymorpha var. tunisiense var. nov. (Coscinodiscophyceae, Bacillariophyta) in the Bay of Tunis: Ultrastructural observations and spatio-temporal distribution. Bot. Mar. 48, 58-72. https://doi.org/10.1515/BOT.2005.009

Daufresne, M., Lengfellner, K., Sommer, U., 2009. Global warming benefits the small in aquatic ecosystems. Proc. Natl. Acad. Sci. U. S. A. 106, 12788-12793. https://doi.org/10.1073/pnas.0902080106

Edler Lars, Elbrächter Malte, 2010. The Utermöhl method for quantitative phytoplankton analysis. Microsc. Mol. Methods Quant. Phytoplankt. Anal. 16-23.

Edwards, M., Richardson, A.J., 2004. Impact of climate change on marine pelagic phenology and trophic mismatch. Nature 430, 881-884. https://doi.org/10.1038/nature02808

Falkowski, P.G., Oliver, M.J., 2007. Mix and match: how climate selects phytoplankton. Nat. Rev. Microbiol. 5, 813-819.

Giorgi, F., 2006. Climate change hot-spots. Geophys. Res. Lett. 33. https://doi.org/10.1029/2006GL025734

Goffart, A., Hecq, J.H., Legendre, L., 2002. Changes in the development of the winterspring phytoplankton bloom in the Bay of Calvi (NW Mediterranean) over the last two decades: A response to changing climate? Mar. Ecol. Prog. Ser. 236, 45-60. https://doi.org/10.3354/meps236045

Gualdi, S., Somot, S., Li, L., Artale, V., Adani, M., Bellucci, A., Braun, A., Calmanti, S., Carillo, A., Dell'Aquila, A., Déqué, M., Dubois, C., Elizalde, A., Harzallah, A., Jacob, D., L'Hévéder, B., May, W., Oddo, P., Ruti, P., Sanna, A., Sannino, G., Scoccimarro, E., Sevault, F., Navarra, A., 2013. The CIRCE simulations: Regional climate change projections with realistic representation of the mediterranean sea. Bull. Am. Meteorol. Soc. 94, 65-81. https://doi.org/10.1175/BAMS-D-11-00136.1

Guinder, V.A., Molinero, J.C., Popovich, C.A., Marcovecchio, J.E., Sommer, U., 2012. Dominance of the planktonic diatom Thalassiosira minima in recent summers in the Bahia Blanca Estuary, Argentina. J. Plankton Res. 34, 995-1000. https://doi.org/10.1093/plankt/fbs060

Hallegraeff, G.M., 1993. A review of harmful algal blooms and their apparent global increase. Phycologia 32, 79-99. https://doi.org/10.2216/i0031-8884-32-2-79.1 
1 Hertig, E., Jacobeit, J., 2008. Assessments of Mediterranean precipitation changes for the 21 st century using statistical downscaling techniques. Int. J. Climatol. 28, 1025-1045. https://doi.org/10.1002/joc.1597

Ibanez, F., Fromentin, J.M., Castel, J., 1993. Application of the cumulated function to the processing of chronological data in oceanography. Comptes Rendus I'Academie des Sci. - Ser. III 316, 745-748.

IPCC, 2014. IPCC,2014: Climate Change 2014: Mitigation of Climate Change.

$$
\text { Contribution of Working Group III to the Fifth Assessment Report of the }
$$

$$
\text { Intergovernmental Panel on Climate Change. Cambridge University Press, }
$$
Cambridge, United Kingdom and New York, NY, USA.

Lazzari, P., Solidoro, C., Ibello, V., Salon, S., Teruzzi, a., Béranger, K., Colella, S., Crise, a., 2012. Seasonal and inter-annual variability of plankton chlorophyll and primary production in the Mediterranean Sea: a modelling approach. Biogeosciences 9, 217-233. https://doi.org/10.5194/bg-9-217-2012

Leblanc, K., Quéguiner, B., Diaz, F., Cornet, V., Michel-Rodriguez, M., Durrieu De Madron, X., Bowler, C., Malviya, S., Thyssen, M., Grégori, G., Rembauville, M., Grosso, O., Poulain, J., De Vargas, C., Pujo-Pay, M., Conan, P., 2018.

Nanoplanktonic diatoms are globally overlooked but play a role in spring blooms and carbon export. Nat. Commun. 9. https://doi.org/10.1038/s41467-018-03376-9

Licandro, P., Conway, D.V.P., Daly Yahia, M.N., Fernandez de Puelles, M.L., Gasparini, S., Hecq, J.H., Tranter, P., Kirby, R.R., 2010. A blooming jellyfish in the northeast Atlantic and Mediterranean. Biol. Lett. 6, 688-691.

$$
\text { https://doi.org/10.1098/rsbl.2010.0150 }
$$

Litchman, E., Klausmeier, C.A., Yoshiyama, K., 2009. Contrasting size evolution in marine and freshwater diatoms. Proc. Natl. Acad. Sci. U. S. A. 106, 2665-2670. https://doi.org/10.1073/pnas.0810891106

Macias, D., Garcia-Gorriz, E., Stips, A., 2013. Understanding the causes of recent warming of mediterranean waters. How much could be attributed to climate change? PLoS One 8, e81591. https://doi.org/10.1371/journal.pone.0081591 Macias, D., Ramirez-Romero, E., Garcia, C.M., 2010. Effect of nutrient input frequency on the structure and dynamics of the marine pelagic community: A modeling approach. J. Mar. Res. 68, 119-151. https://doi.org/10.1357/002224010793078979

Marañón, E., Cermeño, P., Latasa, M., Tadonléké, R.D., 2015. Resource supply alone explains the variability of marine phytoplankton size structure. Limnol. Oceanogr. 
60, 1848-1854. https://doi.org/10.1002/Ino.10138

Marañón, E., Cermeño, P., Latasa, M., Tadonléké, R.D., 2012. Temperature, resources, and phytoplankton size structure in the ocean. Limnol. Oceanogr. 57, 1266-1278. https://doi.org/10.4319//o.2012.57.5.1266

Marañón, E., Cermeño, P., López-Sandoval, D.C., Rodríguez-Ramos, T., Sobrino, C., Huete-Ortega, M., Blanco, J.M., Rodríguez, J., 2013. Unimodal size scaling of phytoplankton growth and the size dependence of nutrient uptake and use. Ecol. Lett. 16, 371-9. https://doi.org/10.1111/ele.12052

Marty, J.C., Chiavérini, J., Pizay, M.D., Avril, B., 2002. Seasonal and interannual dynamics of nutrients and phytoplankton pigments in the western Mediterranean Sea at the DYFAMED time-series station (1991-1999). Deep. Res. Part II Top. Stud. Oceanogr. 49, 1965-1985. https://doi.org/10.1016/S0967-0645(02)00022-X Millot, C., 1999. Circulation in the Western Mediterranean Sea. J. Mar. Syst. 20, 423442. https://doi.org/10.1016/S0924-7963(98)00078-5

Molinero, J., Ibanez, F., Souissi, S., Buecher, E., Dallot, S., Nival, P., 2008. Climate control on the long-term anomalous changes of zooplankton communities in the Northwestern Mediterranean. Glob. Chang. Biol. 14, 11-26.

Mozetič, P., Francé, J., Kogovšek, T., Talaber, I., Malej, A., 2012. Plankton trends and community changes in a coastal sea (northern Adriatic): Bottom-up vs. top-down control in relation to environmental drivers. Estuar. Coast. Shelf Sci. 115, 138148. https://doi.org/10.1016/j.ecss.2012.02.009

Mozetič, P., Solidoro, C., Cossarini, G., Socal, G., Precali, R., Francé, J., Bianchi, F., De Vittor, C., Smodlaka, N., Fonda Umani, S., 2010. Recent trends towards oligotrophication of the northern adriatic: Evidence from chlorophyll a time series. Estuaries and Coasts 33, 362-375. https://doi.org/10.1007/s12237-009-9191-7

Munawar, M., Munawar, I.F., 1986. The seasonality of phytoplankton in the North American Great Lakes , a comparative synthesis. Hydrobiologia 85-115.

Paerl, H.W., Huisman, J., 2008. Blooms like it hot. Science 320, 57-58. https://doi.org/10.1126/science.1155398

Paerl, H.W., Paul, V.J., 2012. Climate change: Links to global expansion of harmful cyanobacteria. Water Res. 46, 1349-1363. https://doi.org/10.1016/j.watres.2011.08.002

Peter, K.H., Sommer, U., 2013. Phytoplankton Cell Size Reduction in Response to Warming Mediated by Nutrient Limitation. PLoS One 8, 1-7. https://doi.org/10.1371/journal.pone.0071528 
1 Pisano, A., Buongiorno Nardelli, B., Tronconi, C., Santoleri, R., 2016. The new Mediterranean optimally interpolated pathfinder AVHRR SST Dataset (19822012). Remote Sens. Environ. 176, 107-116. https://doi.org/10.1016/j.rse.2016.01.019

Platt, T., Li, W.K.W., North Atlantic Treaty Organization. Scientific Affairs Division., 1986. Photosynthetic picoplankton. Can Bull Fish Aquat Sci 214, 583.

Ptacnik, R., Solimini, A.G., Andersen, T., Tamminen, T., Brettum, P., Lepisto, L., Willen, E., Rekolainen, S., 2008. Diversity predicts stability and resource use efficiency in natural phytoplankton communities. Proc. Natl. Acad. Sci. 105, 51345138. https://doi.org/10.1073/pnas.0708328105

Purcell, J.E., Tilves, U., Fuentes, V.L., Milisenda, G., Olariaga, A., Sabatés, A., 2014. Digestion times and predation potentials of Pelagia noctiluca eating fish larvae and copepods in the NW Mediterranean Sea. Mar. Ecol. Prog. Ser. 510, 201-213. https://doi.org/10.3354/meps 10790

Regier, P., Briceño, H., Boyer, J.N., 2019. Analyzing and comparing complex environmental time series using a cumulative sums approach. MethodsX 6, 779787. https://doi.org/10.1016/j.mex.2019.03.014

Ribera d'Alcalà, M., Conversano, F., Corato, F., Licandro, P., Mangoni, O., 2004. Seasonal patterns in plankton communities in a pluriannual time series at a coastal Mediterranean site ( Gulf of Naples ): an attempt to discern recurrences and trends. Sci. Mar. 68, 65-83. https://doi.org/10.3989/scimar.2004.68s165

Root, T., Price, J., Hall, K., Schneider, S., 2003. Fingerprints of global warming on wild animals and plants. Nature 421, 57-60. https://doi.org/10.1038/nature01309.1.

Sala, E., Knowlton, N., 2006. Global Marine Biodiversity Trends. Annu. Rev. Environ. Resourc. 31, 93-122. https://doi.org/Doi 10.1146/Annurev.Energy.31.020105.100235

Shaltout, M., Omstedt, A., 2014. Recent sea surface temperature trends and future scenarios for the Mediterranean Sea. Oceanologia 56, 411-443. https://doi.org/10.5697/oc.56-3.411

Sommer, U., Adrian, R., De Senerpont Domis, L., Elser, J.J., Gaedke, U., Ibelings, B., Jeppesen, E., Lürling, M., Molinero, J.C., Mooij, W.M., van Donk, E., Winder, M., 2012. Beyond the Plankton Ecology Group (PEG) Model: Mechanisms Driving Plankton Succession. Annu. Rev. Ecol. Evol. Syst. 43, 429-448. https://doi.org/10.1146/annurev-ecolsys-110411-160251

Souissi, S., Yahia-Kéfi, O.D., Yahia, M.N.D., 2000. Spatial characterization of nutrient 
dynamics in the Bay of Tunis (south-western Mediterranean) using multivariate analyses: consequences for phyto- and zooplankton distribution. J. Plankton Res. 22, 2039-2059. https://doi.org/10.1093/plankt/22.11.2039

Stibor, H., Vadstein, O., Diehl, S., Gelzleichter, A., Hansen, T., Hantzsche, F., Katechakis, A., Lippert, B., Løseth, K., Peters, C., Roederer, W., Sandow, M., Sundt-Hansen, L., Olsen, Y., 2004. Copepods act as a switch between alternative trophic cascades in marine pelagic food webs. Ecol. Lett. 7, 321-328. https://doi.org/10.1111/j.1461-0248.2004.00580.x

Suikkanen, S., Pulina, S., Engström-Öst, J., Lehtiniemi, M., Lehtinen, S., Brutemark, A., 2013. Climate Change and Eutrophication Induced Shifts in Northern Summer Plankton Communities. PLoS One 8, 1-10. https://doi.org/10.1371/journal.pone.0066475

Thomas, M.K., Kremer, C.T., Klausmeier, C. a., Litchman, E., 2012. A Global Pattern of Thermal Adaptation in Marine Phytoplankton. Science (80-. ). 1085. https://doi.org/10.1126/science.1224836

Tiselius, P., Møller, L.F., 2017. Community cascades in a marine pelagic food web controlled by the non-visual apex predator Mnemiopsis leidyi. J. Plankton Res. 39, 271-279. https://doi.org/10.1093/plankt/fbw096

Utermöhl, H., 1958. Zur Vervollkommnung der quantitativen Phytoplankton-Methodik. SIL Commun. 1953-1996 9, 1-38. https://doi.org/10.1080/05384680.1958.11904091

Vergés, A., Steinberg, P.D., Hay, M.E., Poore, A.G.B., Campbell, A.H., Ballesteros, E., Heck, K.L., Booth, D.J., Coleman, M.A., Feary, D.A., Figueira, W., Langlois, T., Marzinelli, E.M., Mizerek, T., Mumby, P.J., Nakamura, Y., Roughan, M., van Sebille, E., Gupta, A. Sen, Smale, D.A., Tomas, F., Wernberg, T., Wilson, S.K., 2014. The tropicalization of temperate marine ecosystems : climate-mediated changes in herbivory and community phase shifts The tropicalization of temperate marine ecosystems : climate-mediated changes in herbivory and community phase shifts. Proc. R. Socienty B 281, 1-10. https://doi.org/10.1098/rspb.2014.0846

Volpe, G., Colella, S., Forneris, V., Tronconi, C., Santoleri, R., 2012. The Mediterranean Ocean Colour Observing System \&amp;ndash; system development and product validation. Ocean Sci. 8, 869-883. https://doi.org/10.5194/os-8-869-2012 Yahia, M.N.D., Batistić, M., Lucic, D., de Puelles, M.L.F., Licandro, P., Malej, A., 
1 Molinero, J.C., Siokou-Frangou, I., Zervoudaki, S., Prieto, L., Goy, J., Kéfi,

2 O.D.Y.-, 2010. Are the outbreaks timing of Pelagia noctiluca (Forsk\{ä\}l, 1771)

3 getting more frequent in the Mediterranean basin? ICES Coop. Res. Reports 300,

4 8-14.

5 Zingone, A., D’Alelio, D., Mazzocchi, M.G., Montresor, M., Sarno, D., team, L.-M.,

6 2019. Time series and beyond: multifaceted plankton research at a marine

7 Mediterranean LTER site. Nat. Conserv. 34, 273-310.

$8 \quad$ https://doi.org/10.3897/natureconservation.34.30789

9 
1 Figures

2 Figure 1. A- SST yearly averaged anomalies (black dot) and winter precipitation

3 (DJFM, blue dot) along the monitoring period.

4 B-Seasonally averaged chlorophyll time series for: winter (black dot, DJFM) and

5 summer (red square, JJA).

6 C- Cumulative sums for different variables: SST (red square); precipitations (blue dots);

7 chlorophyll winter (dark green diamond); chlorophyll summer (light green diamond).

8 Figure 2. Phytoplankton time series pooled by summer months (red square, JJA) and 9 winter (black dot, DJFM). Cells abundance (log10 cells $\mathrm{L}^{-1}$ ) of total phytoplankton

10 community and derived cusum transformed (A,B); small cells (nanophytoplankton, 2-20

$11 \mu \mathrm{m})$ and derived cusum transform (C,D). Biodiversity of diatoms, collected by the

12 Shannon Index $\left(\mathrm{H}^{\prime}\right)$ and derived cusum transform $(\mathrm{E}, \mathrm{F})$

13 Figure 3. Cell abundances ( $\log 10$ cells $\mathrm{L}^{-1}$ ) for the ten most representative species 14 along the time series: Bellerochea malleus; Bellerochea horologicalis; Thalassionema

15 nitzschioides; Thalassiosira levanderii; Asterionella spp.; Skeletonema costatum;

16 Nitzschia closterium; Merismopedia elegans; Phaeodactylum triconutum. 
1 Table I: Results of average anomalies before/after 2002 after cumulative sums

2 (cusum) analysis (Fig. 1). All variables present before/after 2002 statistically significant

3 differences, $t$ test, $p<0.05)$.

\begin{tabular}{|c|c|c|c|}
\hline \multicolumn{4}{|c|}{ Average anomalies of climatic drivers } \\
\hline \multicolumn{2}{|c|}{ Variable } & $\begin{array}{l}\text { First period (1993- } \\
\text { 2002) }\end{array}$ & Second period (2003-2009) \\
\hline \multicolumn{2}{|l|}{ SST } & -0.407 & 0.581 \\
\hline \multicolumn{2}{|c|}{ Winter precipitations } & -0.590 & 0.843 \\
\hline \multicolumn{4}{|c|}{ Average anomalies of phytoplankton variables } \\
\hline \multicolumn{2}{|c|}{ Variable } & $\begin{array}{l}\text { First period (1993- } \\
\text { 2002) }\end{array}$ & Second period (2003-2009) \\
\hline \multirow[t]{2}{*}{ Chlorophyll } & Winter & $-1,083$ & 0,773 \\
\hline & Summer & $-0,923$ & 0,659 \\
\hline \multirow{2}{*}{$\begin{array}{l}\text { Phytoplankton } \\
\text { cells }\end{array}$} & Winter & -0.412 & 0.454 \\
\hline & Summer & -0.587 & 0.587 \\
\hline \multirow{2}{*}{$\begin{array}{l}\text { Small } \\
\text { phytoplankton } \\
\text { cells }\end{array}$} & Winter & -0.426 & 0.469 \\
\hline & Summer & -0.641 & 0.641 \\
\hline \multirow{2}{*}{$\begin{array}{l}\text { Phytoplankton } \\
\text { biodiversity } \\
\text { Index H' }\end{array}$} & Winter & -0.437 & 0.481 \\
\hline & Summer & -0.565 & 0.565 \\
\hline \multirow{2}{*}{$\begin{array}{l}\text { Diatoms } \\
\text { biodiversity } \\
\text { Index H' }\end{array}$} & Winter & -0.489 & 0.538 \\
\hline & Summer & -0.452 & 0.452 \\
\hline
\end{tabular}




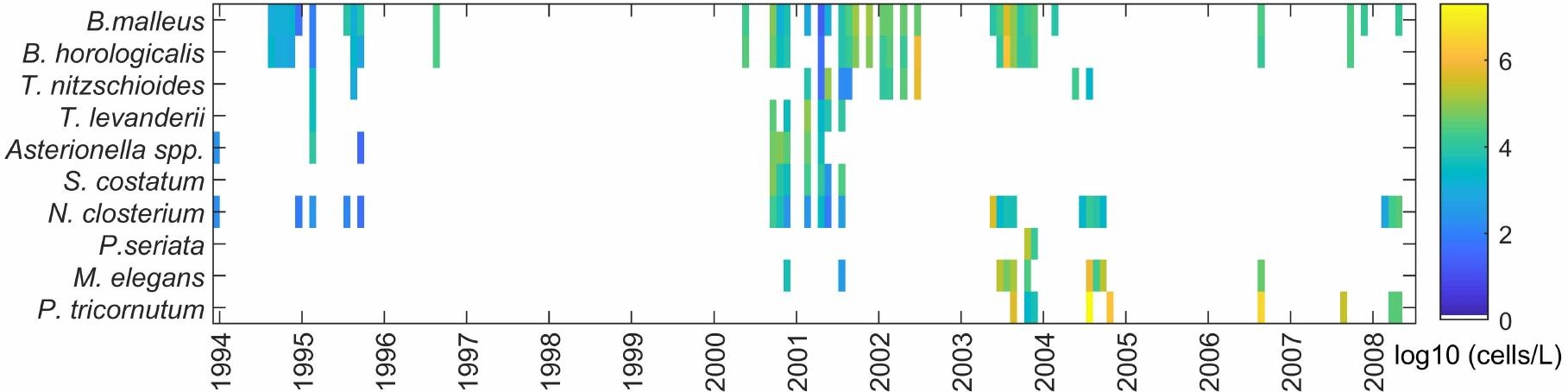


Supplementary Table I: Samples analyzed included in the analysis (Fig.2)

\begin{tabular}{|l|l|l|}
\hline Year & Winter months (DJFM) & Summer months (JJA) \\
\hline 1993 & 3 & - \\
\hline 1994 & $12(1993)$ & 8 \\
\hline 1995 & 2 & $6,7,8$ \\
\hline 1996 & - & 8 \\
\hline 2001 & $12(2000), 1,2$ & 6,7 \\
\hline 2002 & $12(2001), 1,2,3$ & 6 \\
\hline 2003 & 2,3 & $6,7,8$ \\
\hline 2004 & $12(2003), 1,2,3$ & $6,7,8$ \\
\hline 2005 & $12(2004), 1$ & - \\
\hline 2006 & - & 8 \\
\hline 2008 & 1,3 & 8 \\
\hline
\end{tabular}




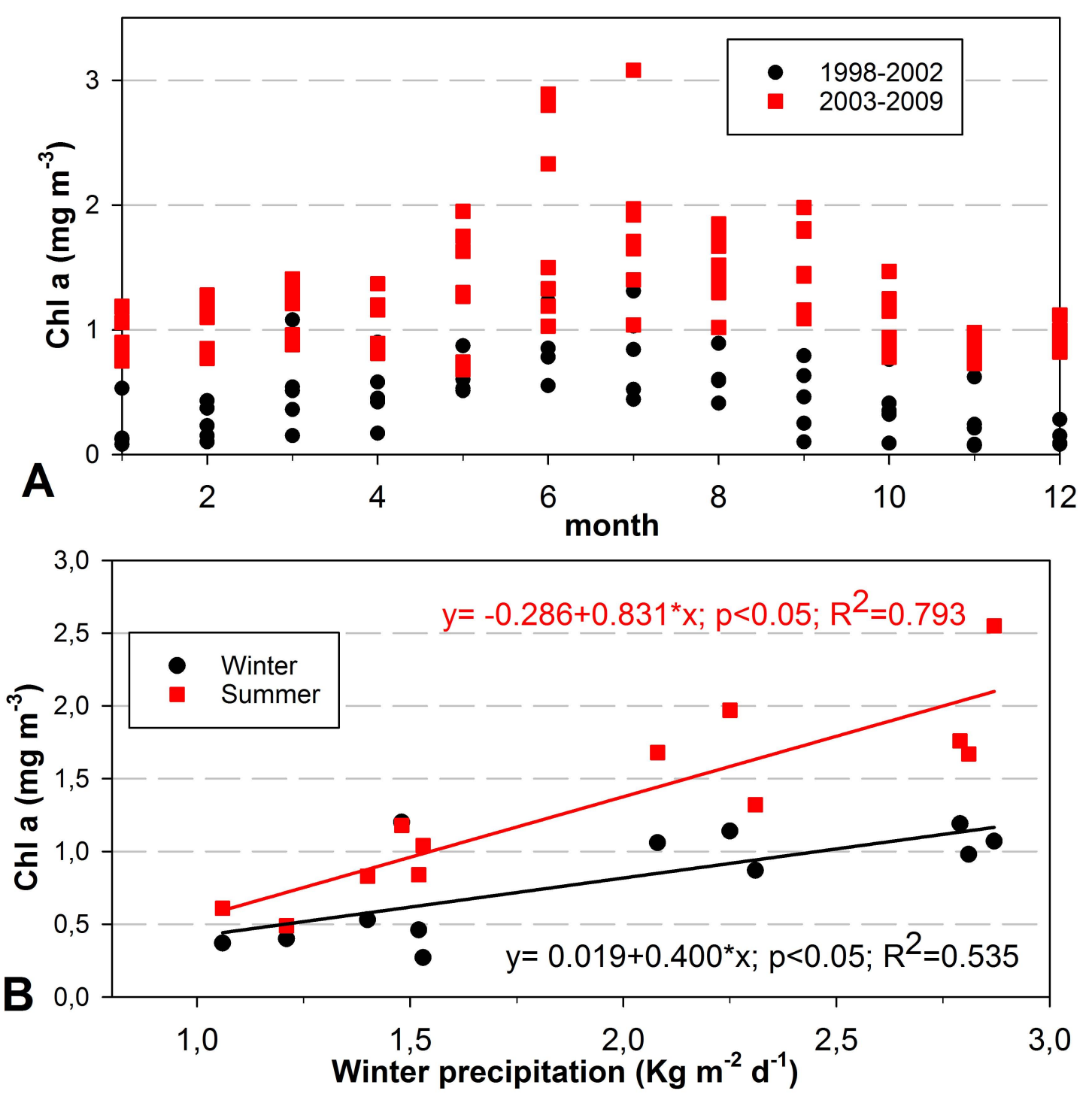



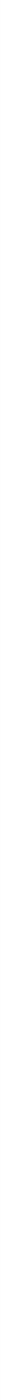
